\title{
New co-polymer zwitterionic matrices for sustained release of verapamil hydrochloride
}

BISTRA KOSTOVA*

DIMITAR RACHEV

Department of Pharmaceutical Technology and Biopharmacy, Faculty of Pharmacy Medical University, Sofia-1000, Bulgaria

\begin{abstract}
Stable co-polymer [vinyl acetate-co-3-dimethyl(methacryloyloxyethyl)ammonium propane sulfonate, $\mathrm{p}$ (VAco-DMAPS)] latex of different compositions has been synthesized for the first time by emulsifier-free emulsion copolymerization. The unusual »overshooting « behavior of the co-polymer tablets has been explained by the formation of specific clusters from the opposite oriented dipoles-zwitterionic species. The change of their concentration with the DMAPS unit fraction (m DMAPS), $\mathrm{pH}$ and ionic strength has been considered responsible for the differences observed in the swelling kinetics. The results obtained prove that m DMAPS and ionic strength could be used to control the swelling degree of the $\mathrm{p}$ (VA-co-DMAPS) matrices and their sustained drug delivery. In this way, $\mathrm{p}$ (VA-co-DMAPS) matrices could be effectively used to control the sustained release of drugs with basic properties like verapamil hydrochloride from model tablets.
\end{abstract}

Keywords: co-polymer [vinyl acetate-co-3-dimethyl(methacryloyloxyethyl)ammonium propane sulfonate, emulsifier-free emulsion copolymerization, polyzwitterion, dipole-dipole clusters, swelling degree, matrix tablets, drug delivery

One of the most effective and widely used methods for preparation of modified release systems is the production of matrix tablets, composed of the drug and polymeric carrier, enabling sustained drug release (1). The development of modified release dosage forms for weakly basic drugs is an important technological challenge. Basic drugs are characterized by $\mathrm{pH}$-dependent solubility, which could significantly influence their release in the gastro-intestinal (GI) tract $(2,3)$. The drug $\mathrm{p} K_{\mathrm{a}}$ value defines its ability to be deprotonated in intestinal fluids, as well as its solubility and release rate (4). This is why it is crucial to provide $\mathrm{pH}$-independent release of such drugs $(5,6)$. Various approaches have been applied: ( $i$ ) addition of organic acids $(2,5)$; (ii) using a combination of a hydrophilic and an enterosolvent polymer $(4,5,7)$; (iii) polymer, whose swelling behavior depends on $\mathrm{pH}$ and the ionic strength of the medium. Polyzwitterions (PZIs) are poly-

\footnotetext{
* Correspondence, e-mail: bistrakostova@abv.bg
} 
mers whose swelling depends strongly on ionic strength. There are some studies $(8,9)$ on the synthesis and properties of PZIs as matrices for drug delivery. PZI's self-association determines their interactions with low-molecular zwitterions (10) and surfactants (11) as their physico-mechanical properties (12). Their self-association in an aqueous solution is due to the dipole-dipole interactions, leading to the formation of dipole-dipole clusters (DDC) (the left hand side in Fig. 1) (13-18). These DDCs are destroyed in the presence of a low-molecular-mass salt (LMS) and the PZI macromolecules swell (Fig. 1). This is the essence of the antipolyelectrolyte effect (APE) $(11,15,16)$. Upon swelling of the PZI macromolecules, the hydrophobic fragments are associated in hydrophobic cores, coated with a hydrophilic shell, consisting of co-ions and their atmosphere (the right hand side in Fig. 1) $(16,19,20)$.

Fig. 1. Reversible destruction of the zwitterionic dipole-dipole clusters (junction points) to single self-neutralizing ionic parts by increasing the ionic strength, and self-association of the PZI macromolecules as amphiphilic structures with a hydrophobic core and a hydrophilic shell after the addition of LMS into aqueous solutions.
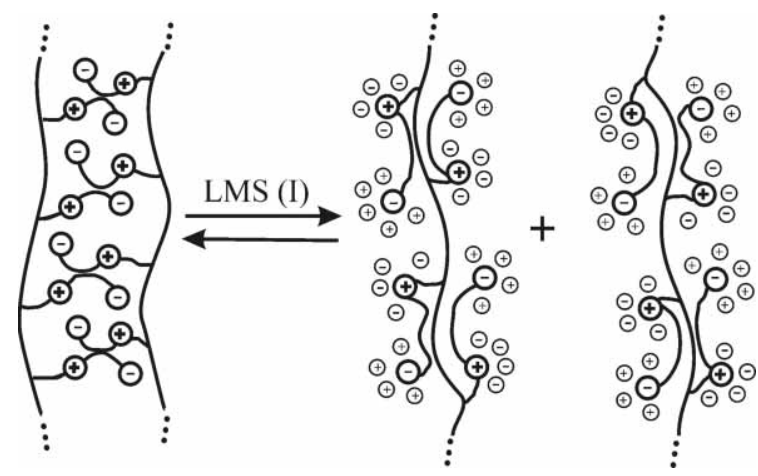

The aim of this study was to evaluate the feasibility of the newly synthesized PZIs latex based on vinyl acetate (VA)-co-3-dimethyl(methacryloyloxyethyl)ammonium propane sulfonate (DMAPS) [p(VA-co-DMAPS)s] as a matrix carrier for verapamil hydrochloride. Thus far, no data about the preparation and application of $\mathrm{p}$ (VA-co-DMAPS) as a matrix for drug delivery could be found. Verapamil hydrochloride is an L-type calcium channel blocker with a class IV antiarrythmic activity (21).

\section{EXPERIMENTAL}

\section{Materials}

Vinyl acetate (VA) (Merck, Germany) was purified by vacuum distillation. 3-Dimethyl(methacryloyloxyethyl)ammonium propane sulfonate (DMAPS) (Merck, Germany) was used as obtained. The initiator potassium peroxide disulfate (KPS, Fluka, Switzerland) was purified by recrystallization from water. Verapamil hydrochloride was supplied by Knoll AG, Germany. Kollidon ${ }^{\circledR}$ SR (polyvinylacetate-polyvinylpyrrolidone, BASF AG, Germany) was used as polymer matrix. Magnesium stearate was used as lubricant (Herwe Chemisch-technische Erzeugnisse, Germany) and silica colloidal dioxide as glidant (Aerosil 200) (Degusa, Germany). 
B. Kostova and D. Rachev: New co-polymer zwitterionic matrices for sustained release of verapamil hydrochloride, Acta Pharm. 57 (2007) 429-439.

\section{Methods}

Emulsifier-free emulsion co-polymerization of VA and DMAPS. - Emulsifier-free emulsion copolymerization (EFC) of VA and DMAPS was performed in water using the method described in our previous paper (22). The VA/DMAPS mole ratios in the monomer feed were 90/10 (co-polymer 1), 85/15 (co-polymer 2), 80/20 (co-polymer 3) and 70/30 (co-polymer 4). p(VA-co-DMAPS)s were obtained as white porous powders, insoluble in water and in most organic solvents.

Elemental analysis. - The co-polymer composition was determined by nitrogen analysis using a Vario EL III elemental analyzer (Elementar Analysensysteme GmbH, Germany).

Swelling kinetics of $p$ (VA-co-DMAPS). - The lyophilized co-polymers 1-4 were molded into tablets of $7 \mathrm{~mm}$ diameter and $2 \mathrm{~mm}$ height. The swelling degree $(Q)$ of the co-polymer samples was determined in an aqueous solution $\left(\mathrm{pH} 1.2-0.1 \mathrm{~mol} \mathrm{~L}^{-1} \mathrm{HCl}\right)$ and in a phosphate buffer solution (PBS) $\left(\mathrm{pH} 6.8-\mathrm{Na}_{2} \mathrm{HPO}_{4} \times 2 \mathrm{H}_{2} \mathrm{O}+\mathrm{KH}_{2} \mathrm{PO}_{4}\right)$ at $37^{\circ} \mathrm{C}$. The ionic strength at $\mathrm{pH} 1.2$ was $0.100 \mathrm{~mol} \mathrm{~L}^{-1}$ and $0.136 \mathrm{~mol} \mathrm{~L}^{-1}$ in PBS. The mass of dry samples was determined after drying in a vacuum oven $\left(60^{\circ} \mathrm{C}\right)$ to constant mass. The dried co-polymer tablets were placed into $20-\mathrm{mL}$ aqueous solution $(\mathrm{pH} 1.2)$ and in PBS ( $\mathrm{pH}$ 6.8). The mass of wet samples was determined after removal of surface water by blotting with filter paper. For each co-polymer, the average value of $Q$ was calculated from three tablets.

Preparation of matrix tablets. - Sustained release (SR) tablets were prepared using polymer carriers: (i) p(VA-co-DMAPS); (ii) Kollidon ${ }^{\circledR}$ SR. All tablets contained $120 \mathrm{mg}$ verapamil hydrochloride, $125 \mathrm{mg}$ co-polymers 1 to 4 or Kollidon ${ }^{\circledR}$ SR, $1 \%(\mathrm{~m} / \mathrm{m})$ magnesium stearate and $1 \%(\mathrm{~m} / \mathrm{m})$ silica colloidal dioxide. The Kollidon ${ }^{\circledR}$ SR matrix tablets were prepared by the method of direct compression, and p(VA-co-DMAPS) matrix tablets were prepared by wet granulation.

Preparation of direct compression matrix tablets. - Direct compression matrix tablets were prepared using the polymer carrier Kollidon ${ }^{\circledR}$ SR with verapamil hydrochloride as follows: verapamil hydrochloride and Kollidon ${ }^{\circledR}$ SR were dry mixed in a HLSH2-6 high shear mixing granulator (Bamtri, China) for $25 \mathrm{~min}$ at $300 \mathrm{rpm}$. Magnesium stearate and silica colloidal dioxide (Aerosil 200) were added and mixed for another $5 \mathrm{~min}$. The blend obtained was tableted to $250 \mathrm{mg}$ using a set of $9 \mathrm{~mm}$-diameter standard concave punches and a single punch tablet press (EK 0, Korsch, Germany).

Preparation of wet granulation matrix tablets. - Wet granulated tablets with verapamil hydrochloride and $\mathrm{p}$ (VA-co-DMAPS) were prepared by dry mixing of both compounds using a HLSH2-6 high shear mixing granulator (Bamtri, China) for $25 \mathrm{~min}$ at $300 \mathrm{rpm}$. Isopropanol was added as a wetting agent dropwise under stirring at $500 \mathrm{rpm}$. The mixture obtained was granulated and passed through a $1500-\mu \mathrm{m}$ sieve. The granules obtained were spread evenly on a tray and dried for $8 \mathrm{~h}$ at $40{ }^{\circ} \mathrm{C}$. Each granule formulation was passed through an $800-\mu \mathrm{m}$ sieve and dry-blended with magnesium stearate and silica colloidal dioxide (Aerosil 200) for $5 \mathrm{~min}$. The resultant blend was tableted as stated for direct compression matrix tablets. 
In vitro drug dissolution studies. - Drug release profiles were evaluated using a dissolution test apparatus (Erweka DT 600, Germany). The USP paddle method was applied (23). The test was carried out at a paddle rotation speed of $50 \mathrm{rpm}$, in $900 \mathrm{~mL}$ dissolution medium maintained at $37 \pm 0.5^{\circ} \mathrm{C}$ at three different $\mathrm{pH}$ values: (i) $\mathrm{pH} 1.2$; (ii) $\mathrm{pH}$ 6.8; (iii) throughout the release experiments, $\mathrm{pH}$ was changed in order to evaluate the effect of $\mathrm{pH}$ (ionic strength) modification. For this purpose, the tablets were first immersed in 0.1 mol L-1 $\mathrm{HCl}$ solution ( $\mathrm{pH}$ 1.2) for $2 \mathrm{~h}$ and were then transferred into PBS solution ( $\mathrm{pH}$ 6.8) for $6 \mathrm{~h}$. Five $\mathrm{mL}$ aliquots of dissolution media were withdrawn at selected intervals up to $8 \mathrm{~h}$. Each sample was filtered through a $0.45-\mu \mathrm{m}$ membrane filter (Sartorius cellulose acetate filter, Germany). The quantity of the drug in the sample solution was determined by UV spectroscopy (absorbance at $278 \pm 2 \mathrm{~nm}$ ) using a Hewlett-Packard 8452 A Diode Array spectrophotometer (USA). The cumulative percentage of drug release was calculated and the average of six determinations was used in the data analysis.

\section{RESULTS AND DISCUSSION}

\section{Characterization of the $p$ (VA-co-DMAPS) co-polymers}

A new $\mathrm{p}$ (VA-co-DMAPS) latex with different compositions has been synthesized by EFC. The preliminary screening of $\mathrm{p}$ (VA-co-DMAPS) matrices suggested that only four co-polymer compositions (1-4) exhibit the desired verapamil hydrochloride release. Their characteristics are given in Table I. The results show that the co-polymers are enriched in DMAPS units. One of the most significant results obtained is that although no emulsifier was used, the obtained microspheres were of small average diameter $(200 \mathrm{~nm})$. This is especially important for the performance of these co-polymers as sustained drug delivery matrices. This effect could be related to the favourable co-monomer hydrophobic-hydrophilic ratio in the copolymerization mixture.

\section{Swelling behavior of $p(V A-c o-D M A P S)$ matrices}

In general, $Q$ is related to the osmotic pressure, cross-linking density and co-polymer affinity to adsorb water (24). Being a zwitterionic monomer, DMAPS has a zero total

Table I. Characteristics of the synthesized co-polymers ${ }^{a}$

\begin{tabular}{cccc}
\hline $\begin{array}{c}\text { Co-polymer } \\
\text { No. }\end{array}$ & $\begin{array}{c}\text { Monomer feed } \\
(\text { VA, mol \%) }\end{array}$ & $\begin{array}{c}\text { Elemental analysis } \\
\text { N (\%) }\end{array}$ & $\begin{array}{c}\text { Co-polymer composition } \\
\text { (VA, mol \%) }\end{array}$ \\
\hline 1 & 90 & 1.73 & 86.03 \\
2 & 85 & 2.30 & 80.00 \\
3 & 80 & 2.74 & 73.00 \\
4 & 70 & 2.92 & 67.99 \\
\hline
\end{tabular}

a Total monomer concentration: $7.5 \times 10^{-2} \mathrm{~mol} \mathrm{~L}^{-1}$; [KPS]: $1 \%(\mathrm{~m} / \mathrm{m})$; solvent: distilled water; temperature: $49 \pm 1{ }^{\circ} \mathrm{C}$; VA - vinylacetate. 
monomer charge, so the main effect on $Q$ is the affinity to water. The ability of the $\mathrm{p}$ (VAco-DMAPS) matrix to swell in aqueous solutions depends on the mole fraction of DMAPS units in the co-polymer ( $\left.\mathrm{m}_{\mathrm{DMAPS}}\right), \mathrm{pH}$ (ionic strength). It could be assumed that by varying $\mathrm{m}_{\mathrm{DMAPS}}$ and ionic strength, it should be possible not only to change the swelling degree of $\mathrm{p}$ (VA-co-DMAPS)s, but also to control the rate of drug release in the GI tract.

The $Q$ values of $\mathrm{p}$ (VA-co-DMAPS) matrices as a function of time at $\mathrm{pH} 1.2$ and 6.8 at $37^{\circ} \mathrm{C}$ are shown in Figs. 2a and b. As it is seen in Figs. 2a and b, $Q$ values increase rapidly and then decrease. This process is more clearly pronounced at $\mathrm{pH} 1.2$. This phenomenon is known as "overshooting " and is attributed to the slow macromolecular relaxation (24). From the dependencies in Figs. 2a and b, it can be clearly seen that the »overshooting " phenomenon has been observed by all co-polymers. At a high diffusion rate of both water and LMS molecules in the co-polymer matrix, the large macromolecules have not enough time to rearrange to the equilibrium structural organization, specific to each co-polymer. Large numbers of intermolecular bonds are destroyed during this fast diffusion and their recovery to reach the above mentioned equilibrium structural organization leads to a decrease in the $Q$ value. The DDC (the left hand side in Fig. 1) represents the physical nodes between different fragments of the co-polymer macromolecule or between different macromolecules. The relationship between these junctions, which could be reversibly destroyed to single self-neutralizing ionic pairs (IPs) (Fig. 1), and the »overshooting " phenomenon is quite interesting.

At the beginning (before immersion of the co-polymer tablets 1-4 into an aqueous solution), most of the zwitterionic units (ZIs) in the co-polymer tablets 1-4 are in IPs form, while the small number of DDC act as physical nodes. When the co-polymer tablets are immersed into an aqueous solution, IPs are first hydrated, since they are more evenly distributed and more accessible. The VA units are hydrophobic and not hydrated. Water molecules diffuse at a higher rate because of the high initial concentration gradient. The hydrated IPs form a phase (hydrophilic phase) separated from the total mass of VA hydrophobic units. The process of two-phase formation, hydrophobic (VA units) and
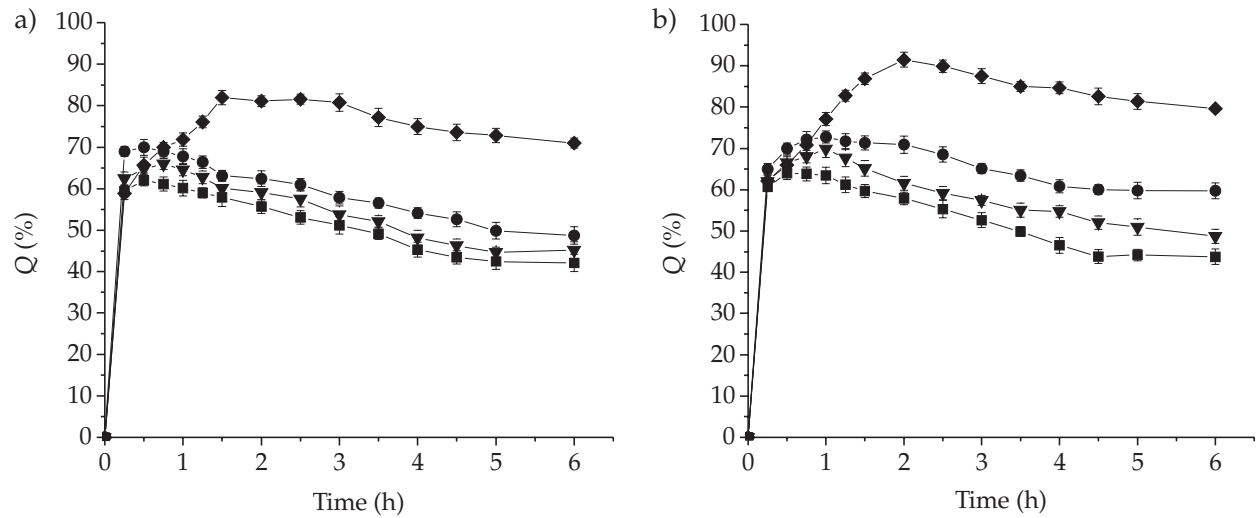

Fig. 2. Swelling kinetics of p(VA-co-DMAPS) matrices at pH: a) 1.2 and b) pH $6.8\left(37^{\circ} \mathrm{C}\right)$; ( $\left.\mathbf{\square}\right)$ co-polymer $1 ;(\nabla)$ co-polymer $2 ;(\bullet)$ co-polymer $3 ;(\diamond)$ co-polymer 4 (mean $\pm \mathrm{SD}, n=3$ ). 
B. Kostova and D. Rachev: New co-polymer zwitterionic matrices for sustained release of verapamil hydrochloride, Acta Pharm. 57 (2007) 429-439.

hydrophilic (hydrated IPs) is hindered by DDC-physical nodes. Therefore, the effect of both ionic strength and $\mathrm{m}_{\text {DMAPS }}$ on the DDC destruction to IPs (Fig. 1) also affects the "overshooting " phenomenon.

The dependencies in Figs. 2a and $\mathrm{b}$ and the data from Table II show that at $\mathrm{pH} 1.2$ the $Q_{\max }$ values for all co-polymers are lower than at $\mathrm{pH}$ 6.8. The higher ionic strength at $\mathrm{pH} 6.8$ (ionic strength $=0.136 \mathrm{~mol} \mathrm{~L}^{-1}$ ) contributes to easier destruction of DDC to IPs (Fig. 1), resulting in higher swelling of the $\mathrm{p}$ (VA-co-DMAPS) matrices.

Table II. $\mathrm{Q}_{\text {max }}$ and relaxation time $\left(\mathrm{t}_{\max }\right.$ values of $p\left(V A-\right.$ co-DMAPS) matrices $^{a}$

\begin{tabular}{ccccc}
\hline $\begin{array}{c}\text { Co-polymer } \\
\text { No. }\end{array}$ & $\begin{array}{c}Q_{\max } \text { at pH } 1.2 \\
(\%)\end{array}$ & $\begin{array}{c}Q_{\max } \text { at } \mathrm{pH} 6.8 \\
(\%)\end{array}$ & $\begin{array}{c}t_{\max } \text { at } \mathrm{pH} 1.2 \\
(\mathrm{~h})\end{array}$ & $\begin{array}{c}t_{\max } \text { at } \mathrm{pH} 6.8 \\
(\mathrm{~h})\end{array}$ \\
\hline 1 & 62.05 & 64.01 & 0.50 & 0.5 \\
2 & 65.98 & 69.88 & 0.45 & 1.0 \\
3 & 69.95 & 72.78 & 0.50 & 1.0 \\
4 & 81.97 & 91.46 & 1.50 & 2.0 \\
\hline
\end{tabular}

a Temperature: $37^{\circ} \mathrm{C}$

Despite the relatively narrow limits of m DMAPS, the changes of its values affect the swelling kinetics of the p(VA-co-DMAPS) matrices. From Figs. 2a and b, it can be seen that with increasing m $m_{\text {DMAPS }}$ in co-polymers $1-4$, the $Q_{\max }$ values also increase at both $\mathrm{pH}$ values. The plot for co-polymer 4 at both $\mathrm{pH}$ values is quite different from the plots obtained for co-polymers 1 to 3 . The action of mDMAPS is twofold: (i) it enhances the hydrophilicity of the co-polymer matrix (especially for co-polymer 4, exhibiting the highest m DMAPS value); (ii) increases DDC density, size and precision in the co-polymer

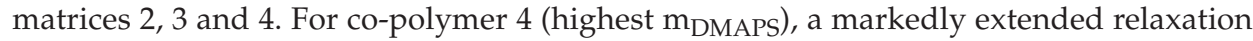
time $\left(t_{\max }\right)$ was observed at both $\mathrm{pH} 1.2$ and 6.8 (Table II). This could be attributed to the higher DDC concentration (in co-polymer 4), their slower destruction and probably slower relaxation.

The $Q_{\max }$ value is reached after the microphase separation into hydrophobic and hydrophilic parts has taken place. In the hydrophilic (swollen) part of the co-polymer matrix, the IPs concentration increases, which helps the equilibrium shift to the left (Fig. 1), leading to the formation of new physical nodes in the aqueous (swollen) phase, contributing to its shrinkage - the $Q$ value decreases. Furthermore, the lower the ionic strength, the higher the probability of physical nodes creation; the p(VA-co-DMAPS) matrices shrink more and the $Q$ value decrease is more strongly pronounces. These results were obtained at $\mathrm{pH} 1.2$ (ionic strength $=0.100 \mathrm{~mol} \mathrm{~L}^{-1}$ ) (Fig. 2a).

The dependencies in Figs. 2a and $b$, showing the swelling behavior of $p$ (VA-coDMAPS) matrices, could be explained as follows. The swelling kinetics of $p$ (VA-co-DMAPS) matrices shows a close relation between the »overshooting « phenomenon and DDC formation, typical of co-polymers with zwitterionic units. Perhaps, the influence of the DDC reversible destruction (Fig. 1) on the specific »overshooting « phenomenon is the- 
B. Kostova and D. Rachev: New co-polymer zwitterionic matrices for sustained release of verapamil hydrochloride, Acta Pharm. 57 (2007) 429-439.

Table III. $p$ (VA-co-DMAPS) and Kollidon ${ }^{\circledR}$ SR tablet composition

\begin{tabular}{ccccc}
\hline $\begin{array}{c}\text { Co-polymer } \\
\text { No. }\end{array}$ & $\begin{array}{c}\text { Verapamil hydro- } \\
\text { chloride mass }(\mathrm{mg})\end{array}$ & $\begin{array}{c}\text { Co-polymer } \\
\text { mass }(\mathrm{mg})\end{array}$ & $\begin{array}{c}\text { Silica colloidal } \\
\text { dioxide }(\%, \mathrm{~m} / \mathrm{m})\end{array}$ & $\begin{array}{c}\text { Magnesium } \\
\text { stearate }(\%, \mathrm{~m} / \mathrm{m})\end{array}$ \\
\hline 1 & 120 & 125 & 1 & 1 \\
2 & 120 & 125 & 1 & 1 \\
3 & 120 & 125 & 1 & 1 \\
4 & 120 & 125 & 1 & 1 \\
Kollidon $^{\circledR}$ SR & 120 & 125 & 1 & 1 \\
\hline
\end{tabular}

reby explained for the first time. The above discussed results reveal that $m_{\text {DMAPS }}$ and ionic strength (LMS) affect the reversible equilibrium between DDC and IPs (Fig. 1), defining the $Q$ value.

\section{Release of verapamil hydrochloride from tablets with $p$ (VA-co-DMAPS) matrices}

Verapamil hydrochloride, characterized by $\mathrm{p} K_{\mathrm{a}}=8.6(25)$, was chosen as a model drug. It is soluble in water $\left(82 \mathrm{mg} \mathrm{mL}^{-1}\right.$ at $\mathrm{pH} 2.32,11 \mathrm{mg} \mathrm{mL}^{-1}$ at $\mathrm{pH} 6.76$ (26), and practically insoluble in basic solutions (27).

The composition of the p(VA-co-DMAPS)-based tablet formulations studied is shown in Table III. Kollidon ${ }^{\circledR}$ SR-based model formulations were used as reference.

The release profiles of verapamil hydrochloride from the model $\mathrm{p}$ (VA-co-DMAPS) tablets at pH 1.2 and $\mathrm{pH} 6.8$ are presented in Figs. 3a and b. The dependencies show the influence of the mDMAPS values on the release profiles after $6 \mathrm{~h}$. The amount of drug released from co-polymer 4-based formulation at $\mathrm{pH} 1.2$ reached $73.4 \%$ after $8 \mathrm{~h}$. This result suggests that the high solubility of verapamil hydrochloride at $\mathrm{pH} 1.2$ leads to a higher release rate despite the lower swelling degree of the $\mathrm{p}$ (VA-co-DMAPS) matrices at this $\mathrm{pH}$.

At pH 6.8 (Fig. 3b), the release rate could be expected to be markedly lower. However, the results obtained (Fig. $3 b$ ) do not confirm this assumption - after $8 \mathrm{~h}$ the amount of drug released from co-polymer 4-based matrices reached $51.7 \%$. This result could be explained by the effect of APE (the presence of LMS and higher ionic strength at $\mathrm{pH}$ 6.8) on the swelling degree of $\mathrm{p}$ (VA-co-DMAPS) matrices. This high swelling degree compensates for the very low solubility of verapamil hydrochloride at this $\mathrm{pH}$.

The drug release profiles from the four model p(VA-co-DMAPS) matrices and the matrix based on Kollidon ${ }^{\circledR}$ SR were investigated under varying $\mathrm{pH}$ values as well (Fig. 4). First, both $\mathrm{p}$ (VA-co-DMAPS) and Kollidon ${ }^{\circledR}$ SR tablets were put for $2 \mathrm{~h}$ in dissolution media with $\mathrm{pH}$ 1.2, then for $6 \mathrm{~h}$ at $\mathrm{pH}$ 6.8. The results obtained (Fig. 4), show that with increasing $\mathrm{m}_{\text {DMAPS }}$ in the $\mathrm{p}$ (VA-co-DMAPS) matrices, the verapamil hydrochloride release rate was also increased. The difference between the release rates for co-polymers 1 and 4 after $8 \mathrm{~h}$ is about $6.5 \%$. The m DMAPS increase in p(VA-co-DMAPS) tablets results in enhanced possibility of DDC destruction as well as a higher swelling rate. The equilibrium in Fig. 1 is shifted to IPs, which permits faster diffusion of verapamil hydrochlo- 

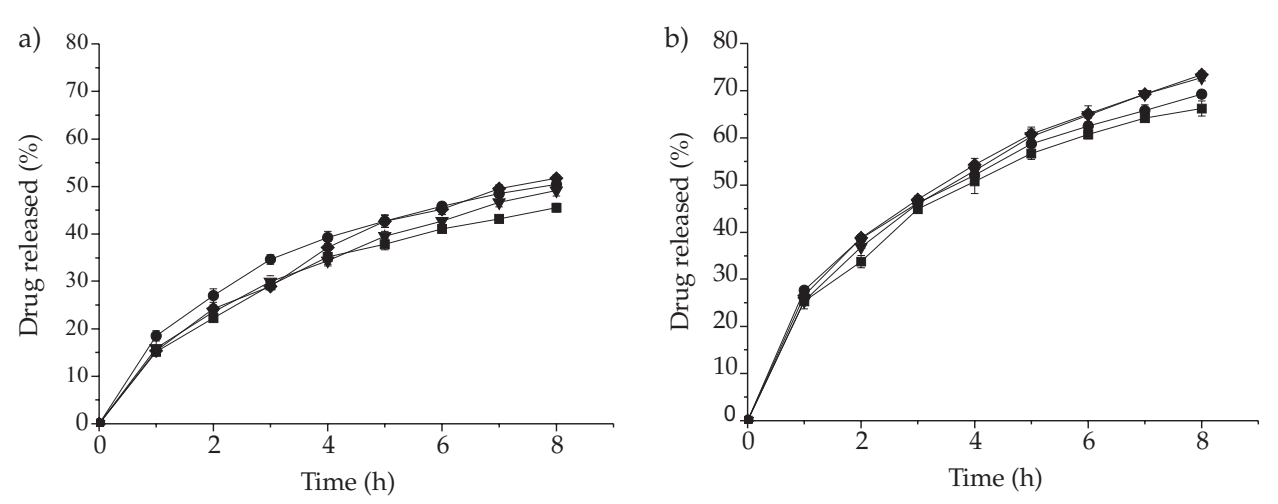

Fig. 3. Release kinetics of verapamil hydrochloride from model $\mathrm{p}$ (VA-co-DMAPS) tablets at $\mathrm{pH}$ : a) 1.2 and b) pH $6.8\left(37^{\circ} \mathrm{C}\right) ;(\boldsymbol{\nabla})$ co-polymer $1 ;(\boldsymbol{\nabla})$ co-polymer 2; $(\bullet)$ co-polymer 3; $(\diamond)$ co-polymer 4 (mean $\pm \mathrm{SD}, n=6)$.

ride from the gel structure. Hence, the release profile of verapamil hydrochloride can be modified just by varying m DMAPS in $\mathrm{p}$ (VA-co-DMAPS)s.

The results presented in Fig. 4 clearly indicate that all p(VA-co-DMAPS) matrices release verapamil hydrochloride at higher rates compared to Kollidon ${ }^{\circledR}$ SR. After 8 h, matrices based on p(VA-co-DMAPS) released $49.8 \%$ to $56.1 \%$ verapamil hydrochloride, while the amount of released drug from Kollidon ${ }^{\circledR}$ SR matrix was only 39.5\%. The difference in the amount of released verapamil hydrochloride after $8 \mathrm{~h}$ from Kollidon ${ }^{\circledR}$ SR matrix and co-polymer 4 (higher $\mathrm{m}_{\mathrm{DMAPS}}$ ) is more than $16 \%$ while in case of co-polymer 1 , this difference is only $10 \%$. These values could be attributed mainly to the PZI character of the p(VA-co-DMAPS) matrix. In the case of Kollidon ${ }^{\circledR} \mathrm{SR}$ matrix [a physical mixture of poly(VA) and poly(N-vinyl pyrrolidone) poly(NVP)], the swelling behavior is $\mathrm{pH}$-independent. However, this behavior of the Kollidon ${ }^{\circledR}$ SR matrix (without addition of subsidiary materials like enterosolvent polymers and organic acids) is not favorable in the case of verapamil hydrochloride and this is the reason for its low release rate. The pre-

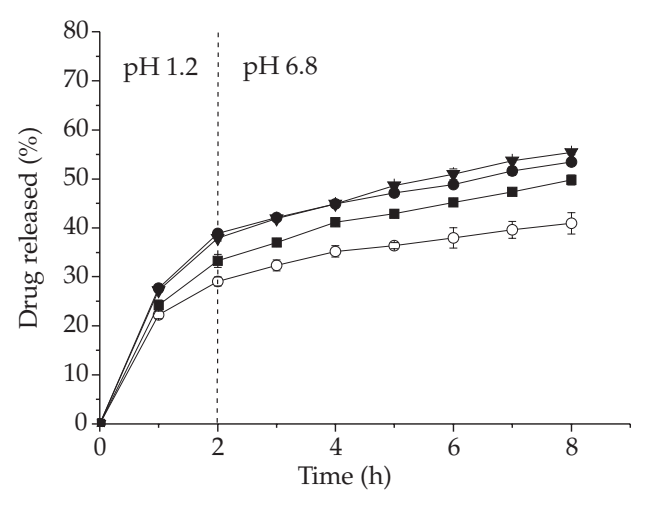

Fig. 4. Release kinetics of verapamil hydrochloride from model $\mathrm{p}$ (VA-co-DMAPS) tablets and from Kollidon ${ }^{\circledR}$ SR at $\mathrm{pH} 1.2$ (the first 2 hours) and at $\mathrm{pH} 6.8$ (after the second hour) $\left(37^{\circ} \mathrm{C}\right) ;(\mathbf{\square})$ co-polymer $1 ;(\boldsymbol{\nabla})$ co-polymer $2 ;(\bullet)$ co-polymer 3; $(\diamond)$ co-polymer 4; (O) Kollidon ${ }^{\circledR}$ $\mathrm{SR}$ (mean $\pm \mathrm{SD}, n=6$ ). 
sented results demonstrate the advantages of the newly synthesized $p$ (VA-co-DMAPS) matrices. Due to their specific zwitterionic structure, higher drug release in the GI tract could be achieved.

According to Streubel et al. (5) ethyl cellulose polymer matrices released 34\% verapamil hydrochloride after $8 \mathrm{~h}$ at $\mathrm{pH}$ 6.8. The same authors explained that formulations based on the intensively swelling HPMC in 1:1 ratio $(\mathrm{m} / \mathrm{m})$ to lactose in these conditions released only $17 \%$ of the drug after $8 \mathrm{~h}$. The comparison of these release profiles with our results shows that $\mathrm{p}$ (VA-co-DMAPS)s, especially those with higher m $\mathrm{DMAPS}_{\text {(co-po- }}$ lymers 3 and 4), are effective and suitable matrices for incorporation of verapamil hydrochloride and possibly of other drugs with similar physicochemical properties.

\section{CONCLUSIONS}

It has been established that the newly synthesized $\mathrm{p}$ (VA-co-DMAPS)s are promising candidates for matrix carriers of verapamil hydrochloride and possibly of other drugs with basic properties. Specific structure organization of a $\mathrm{p}$ (VA-co-DMAPS)s permits to solve the problems associated with the release behavior and makes them advantageous over other polymer matrices.

\section{REFERENCES}

1. M. Gohel, T. Patel and Sh. Bariya, Studies in preparation and evaluation of $\mathrm{pH}$-independent sustained-release matrix tablets of verapamil $\mathrm{HCl}$ using directly compressible Eudragits, Pharm. Dev. Technol. 8 (2003) 323-333; DOI: 10.1081/PDT-120024686.

2. K. Gabr, Effect of organic acids on release patterns of weakly basic drugs from innert sustained release matrix tablets, Eur. J. Pharm. Biopharm. 38 (1992) 199-202.

3. M. Dimitrov and N. Lambov, Study of verapamil hydrochloride release from compressed hydrophilic Polyox-Wsr tablets, Int. J. Pharm. 189 (1999) 105-111; DOI: 10.1016/S0378-5173(99) 00242-2.

4. A. Tatavarti, K. Menta, L. Augsburger and S. Hoag, Influence of methacrylic and acrylic acid polymers on the release performance of weakly basic drugs from sustained release hydrophilic matrices, J. Pharm. Sci. 93 (2004) 2319-2331; DOI: 10.1002/jps.20129.

5. A. Streubel, J. Siepmann, A. Dashevsky and R. Bodmeier, pH-independent release of a weakly basic drug from water-insoluble and -soluble matrix tablets, J. Control. Rel. 67 (2000) 101-110; DOI: 10.1016/S0168-3659(00)00200-5.

6. P. Timmins, A. M. Delargy and J. R. Howard, Optimization and characterization of a $\mathrm{pH}$-independent extended-release hydrophilic matrix tablet, Pharm. Dev. Technol. 2 (1997) 25-31.

7. R. J. MacRae and J. S. Smith, Controlled-release Pharmaceutical Formulations Containing Low Molecular Weight Polyethylene Oxide and Hydroxypropylmethyl Cellulose, WO Pat. 97/18814, 29 May 1997; ref. Chem. Abstr. 127 (1997) 55911u; DOI: 10.1016/0032-3861(94)90913-X.

8. K. Nam, J. Watanabe and K. Ishihara, pH-modulated release of insulin entrapped in a spontaneously formed hydrogel system composed of two water-soluble phospholipid polymers, J. Biomater. Sci., Polym. Ed. 13 (2002) 1259-1269; DOI: 10.1163/156856202320892993. 
B. Kostova and D. Rachev: New co-polymer zwitterionic matrices for sustained release of verapamil hydrochloride, Acta Pharm. 57 (2007) 429-439.

9. M. Blanco, J. Rego and M. Huglin, Drug release with simultaneous dimensional changes from a new copolymeric hydrogel, Polymer 35 (1994) 3487-3491; DOI: 10.1016/0032-3861(94)90913-X.

10. G. Georgiev, E. Kamenska, E. Vassileva, I. Kamenova, V. Georgieva, S. Iliev and I. Ivanov, Properties and biomedical application of polyzwitterions, Ann. Univ. Sofia, Chem. 98-99 (2005) 305325; ref. Chem. Abst. 147 (2007) 196825.

11. I. Ivanov, I. Kamenova, V. Georgieva, E. Kamenska and G. Georgiev, Mixed surfactant-polyzwitterion self-assemblies in aqueous solutions, Colloid Surf. A. Physicochem. Eng. Asp. 282-283 (2006) 129-133; DOI: 10.1016/j.colsurfa.2006.02.038.

12. Ch. Smilkov, I. Kamenova, E. Kamenska, Ch. Betchev and G. Georgiev, Synthesis, Morphology and Structural Characterization of Polysulfobetaine Copolymers as Potential Materials for Medical Applications, in PPS-21: Proceedings of the 21st Annual Meeting of the Polymer Processing Society, Leipzig, June 19-23, 2005, Halle/S. 2005, p. 148.

13. G. Georgiev, A. Tzoneva, L. Lyutov, S. Iliev, I. Kamenova, V. Georgieva, E. Kamenska and A. Bund, Electrostimulated shift of the precipitation temperature of aqueous polyzwitterionic solutions, Macromol. Symp. 210 (2004) 393-401; DOI: 10.1002/masy.200450644.

14. G. Georgiev, I. Kamenova, V. Georgieva, E. Kamenska, R. Hempelmann and H. Natter, Poly(dimethylaminoethylmethacryloylpropanesulfonate) suitable polymer additive for pulsed electrodeposition of nanocrystalline nickel, J. Appl. Polym. Sci. 102 (2006) 2967-2970; DOI: 10.1002/ app. 24574.

15. G. Georgiev, E. Kamenska, E. Vassileva, I. Kamenova, V. Georgieva, S. Iliev and I. Ivanov, Self-assembly, antipolyelectrolyte effect and nonbiofouling properties of polyzwitterions, Biomacromolecules 7 (2006) 1329-1334; DOI: 10.1021/bm050938q.

16. E. Kamenska, E. Vassileva, I. Kamenova, A. Tzoneva, V. Georgieva, S. Iliev and G. Georgiev, A new approach to the description and control of the unique biocompatibility of polyzwitterions, Bulg. Chem. Commun. 38 (2006) 49-54.

17. J. Bredas, R. Chance and R. Silbey, Head-head interactions in zwitterionic associating polymers, Macromolecules 21 (1988) 1633-1639; DOI: 10.1021/ma00184a019.

18. S. Tsonchev, A. Troisi, G. Schatz and M. Ratner, All-atom numerical studies of self-assembly of zwitterionic peptide amphiphiles, J. Phys. Chem. B. 108 (2004) 15278-15284; DOI: 10.1021/jp04788.0e.

19. M. Huglin and J. Rego, Influence of a salt on the properties of hydrogels of 2-hydroxyethyl methacrylate with a sulfobetaine comonomer, Macromolecules 26 (1993) 3118-3126; DOI: 10.1021/ ma00064a020.

20. A. Lowe and C. McCormick, Synthesis and solution properties of zwitterionic polymers, Chem. Rev. 102 (2002) 4177-4190; DOI: 10.1021/cr020371t.

21. A. Elkheshen, Interaction of verapamil hydrochloride with carbopol 934P and its effect on the release rate of the drug and the water uptake of the polymer matrix, Pharm. Dev. Ind. Pharm. 27 (2001) 925-934; DOI: 10.1081/DDC-100107673.

22. E. Kamenska, B. Kostova, I. Ivanov, D. Rachev and G. Georgiev, Emulsifier-free emulsion copolymerization of vinyl acetate-3-dimethyl(methacryloyloxyethyl)-ammonium propane sulfonate and swelling behavior of their copolymer matrices, Macromol. React. (2007) 553-562; DOI: 10.1002/ mren.200700013.

23. United States Pharmacopoeia 28 - National Formulary 23, USP Convention, Rockville 2005, pp. 2412-2414.

24. W. Lee and C. Chen, Poly(2-hydroxyethyl methacrylate-co-sulfobetaine) hydrogels. II. Synthesis and swelling behaviors of the [2-hydroxyethyl methacrylate-co-3-dimethyl(methacryloyloxyethyl) ammonium propane sulfonate] hydrogels, J. Appl. Polym. Sci. 69 (1998) 2021-2034; DOI: 10.1002/(SICI)1097-4628(19980906)69:10<2021::AID-APP14>3.0.CO;2-4.

25. A. Kasim, M. Whitehouse, C. Ramachandran, M. Bermejo, H. Lennernäs, S. Hussain, H. Junginger, S. Stavachansky, K. Midha, V. Shah and G. Amidon, Molecular properties of WHO es- 
B. Kostova and D. Rachev: New co-polymer zwitterionic matrices for sustained release of verapamil hydrochloride, Acta Pharm. 57 (2007) 429-439.

sential drugs and provisional biopharmaceutical classification, Mol. Pharm. 1 (2004) 85-96; DOI: $10.1021 / \mathrm{mp} 034006 \mathrm{~h}$.

26. H. Vogelpoel, J. Welnik, G. Amidon, H. Junginger, K. Midha, H. Möller, M. Oling, V. Shah and D. Barends, Biowaiver monographs for immediate release solid oral dosage forms based on biopharmaceutics classification system (BCS) literature data: Verapamil hydrochloride, Propanolol Hydrochloride, and Atenolol, J. Pharm. Sci. 93 (2004) 1945-1956; DOI: 10.1002/jps.20131.

27. Drug Information - American Hospital Formulary Service (DI-AHFS) (Ed. G. K. McEvoy), American Society of Health-System Pharmacists, Bethesda (MD) 1995, pp. 1148-1152.

\section{$S A \check{Z} E T A K$}

\section{Novi kopolimerni zwitterionski matriksi za polagano oslobađanje verapamil hidroklorida}

BISTRA KOSTOVA i DIMITAR RACHEV

Metodom emulzijske polimerizacije sintetiziran je novi stabilni kopolimer [vinil acetat-ko-3-dimetil(metakriloiloksietill)amonijev propan sulfonat, $\mathrm{p}$ (VA-co-DMAPS)] lateks promjenjivog sastava. Neobično "pretjerano" ponašanje tableta pripravljenih iz tog kopolimera objašnjava se stvaranjem specifičnih klastera suprotno orijentiranih dipola zwitterionskih specija. Proučavan je utjecaj njihovih koncentracija s udjelom DMAPS jedinica (m $\left.m_{\text {DMAPS }}\right), \mathrm{pH}$ i ionskom jakosti na kinetiku bubrenja. Dobiveni rezultati dokazuju da se promjenom m DMAPS $i$ ionske jakosti može kontrolirati stupanj bubrenja p(VA-co-DMAPS) matriksa i oslobađanje verapamil hidroklorida iz tableta pa se ti matriksi mogu upotrijebiti za polagano oslobađanje bazičnih lijekova srodnih verapamilu.

Ključne riječi: kopolimer [vinil acetat-ko-3-dimetil(metakriloiloksietill)amonijev propan sulfonat, emulzijska kopolimerizacija bez emulgatora, polizwitterion, dipol-dipol klasteri, bubrenje, matriksne tablete, isporuka lijekova

Department of Pharmaceutical Technology and Biopharmacy, Faculty of Pharmacy, Medical University Sofia-1000, Bulgaria 